\title{
SPECTROPHOTOMETRY OF NEPTUNIUM IN NITRIC ACID SOLUTIONS
}

\author{
Andrew J. Johnson
}

Glenn A. Shepherd

i.

\section{LEGAL NOTICE}

This report was prepared as an account of Government sponsored work. Nelther the United States, nor the Commission, nor any person acting on behalf of the Commission:

A. Makes any warranty or representation, expressed or implied, with respect to the accuracy, completeness, or usefulness of the information contained in this report, or that the use of any information, apparatus, method, or process disclosed in this report may not infringe privately owned righte; or

B. Assuraes any liabilities with respect to the use of, or for demages resulting from the of any information, apparatus, method, or process disclosed in this report.

use of any information, apparatus, method, or process disclosed in this report.
As used in the above, "person acting on behalf of the Commission" includes any emAs used in the above, "person acting on behalf of the Commisslon" includes any em-
ployee or contractor of the Commission, or omployee of such contractor, to the extent that ployee or contractor of the Commission, or employee of such contractor, to the extent that
such empioyee or contractor of the Commlssion, or employee of such contractor prepares, auch empioyes or contractor of the Commlsaion, or employee of such contractor prepares,
disseminates, or provides access to. any information pursuant to his employment or contract with the Commisaton, or his employment with such contractor.

\footnotetext{
THE DOW CHEMICAL COMPANY

ROCKY FLATS DIVISION

P. O. BOX 888

GOLDEN, COLORADO 80401

U. S. ATOMIC ENERGY COMMISSION

CONTRACT AT $(29-1)-1106$
} 


\section{DISCLAIMER}

This report was prepared as an account of work sponsored by an agency of the United States Government. Neither the United States Government nor any agency Thereof, nor any of their employees, makes any warranty, express or implied, or assumes any legal liability or responsibility for the accuracy, completeness, or usefulness of any information, apparatus, product, or process disclosed, or represents that its use would not infringe privately owned rights. Reference herein to any specific commercial product, process, or service by trade name, trademark, manufacturer, or otherwise does not necessarily constitute or imply its endorsement, recommendation, or favoring by the United States Government or any agency thereof. The views and opinions of authors expressed herein do not necessarily state or reflect those of the United States Government or any agency thereof. 


\section{DISCLAIMER}

Portions of this document may be illegible in electronic image products. Images are produced from the best available original document. 


\title{
SPECTROPHOTOMETRY OF NEPTUNIUM IN NITRIC ACID SOLUTIONS
}

\author{
Andrew J. Johnson and Glenn A. Shepherd
}

\begin{abstract}
Studies have been made of the effect of varying nitric acid concentrations in neptunium solutions on the oxidation states of neptunium present. Spectrophotometric methods were used to determine the proportions of neptunium(IV), (V), and (VI) present in nitric acid solutions varying between one and ten normal ( $1 \underline{N}$ and $10 \underline{N}$ ). Absorption spectra of both the neptunium(IV) and (VI) complexes with nitrate have been identified and are given. (Appropriate Roman numerals are used to denote valences of the materials.)
\end{abstract}

\section{INTRODUCTION}

The different valence states of neptunium $\left(\mathrm{N}_{\mathrm{p}}\right)$ can be qualitatively differentiated by their ultraviolet-visiblenear infrared absorption spectra. ${ }^{1}$ This has been the basis for the quantitative spectrophotometric determination of neptunium methods used elsewhere ${ }^{2}$ and at Rocky Flats. During the development of these methods in the laboratory, it was noted that the nitric acid $\left(\mathrm{HNO}_{3}\right)$ concentration is a critical parameter for accurate analysis. A change in acid concentration affects the absorbance of the analytical absorption bands used, indicating possible complex formation.

The complexing behavior of $\mathrm{Np}$ in $\mathrm{HNO}_{3}$ solutions has been investigated by Ryan ${ }^{3}$ and Keder. ${ }^{4}$ Ryan, in working with quadrivalent actinides, confined his investigations to quadrivalent $\mathrm{Np}$. The work of Keder with $\mathrm{Np}$ (IV) and (VI) was done in a nitric acid-perchloric acid mixture using a tributyl phosphate-xylene extraction.

The current work, in addition to repeating some of Ryan's investigations with $\mathrm{Np}(\mathrm{IV})$, also covers the $\mathrm{HNO}_{3}$ complexes of $\mathrm{Np}(\mathrm{V})$ and (VI). While Keder worked only with $0.1 \underline{\mathrm{N}}$ to $4.0 \mathrm{~N} \mathrm{HNO}_{3}$ solutions, the

\footnotetext{
${ }^{1}$ C. F. Metz and G. R. Waterbury. "The Transuranium Actinide Elements." I. M. Kolthoff, P. F. Elving, and E. B. Sandell, Editors. Treatıse on Analytical Chemıstry. Part II, 9.232. Interscience, New York. 1962.

${ }^{2}$ C. A. Colvin. "Spectrophotometric Determination of Neptunium Using 1.23-Micron Sexivalent Absorption Peak." Analytrcal Chemistry, 35:806. 1963.

${ }^{3}$ J. L. Ryan. "Specres Involved in the Anion-Exchange Absorption of Quadrivalent Actinide Nitrates." Journal of Physical Chem. istry, 64:1375. 1960.

${ }^{4}$ W. E. Keder. "Neptunium Complex Ion Species Extracted from Nitric Acid-Perchloric Acid Mixtures by Tributyl Phosphate." Journal of Inorganic Nuclear Chemistry, 16.138. 1960.
}

complexing behavior of $\mathrm{Np}$ in $\mathrm{HNO}_{3}$ solutions up to 10 N was investigated in this study.

The investigation included study of the effect of a varying concentration of $\mathrm{HNO}_{3}$ in solutions containing the (IV), (V), and (VI) valence states of $\mathrm{Np}$. The complexing effect of nitrate could be observed and would aid in understanding the ion-exchange behavior of $\mathrm{Np}$ in $\mathrm{HNO}_{3}$ solutions.

\section{SUMMARY}

An investigation was undertaken to determine the effect of varying $\mathrm{HNO}_{3}$ concentrations on the oxidation states of $\mathrm{Np}$. Such information has considerable importance in determining the chemistry of $\mathrm{Np}$ in analytical and separation procedures. The behavior of $\mathrm{Np}$ in solvent extraction, carrier precipitation, and ion-exchange processes is dependent upon the valence state of the $\mathrm{Np}$ under the existing conditions.

Spectrophotometric methods were employed to determine the proportions of $\mathrm{Np}(\mathrm{IV}),(\mathrm{V})$, and (VI) present in $\mathrm{HNO}_{3}$ solution varying in concentrations from $1 \underline{\mathrm{N}}$ to $10 \mathrm{~N}$. Since the different valence states of $\mathrm{Np}$ can be differentiated by their absorption spectra, the complexing effects of the nitrate ion can be observed. Thus, an understanding of the ion-exchange and the solvent-extraction behavior of neptunım in nitric acid solutions may be achieved.

Molar (M) absorptivities were calculated using the absorbances found for the major absorption band of each of the species at varying $\mathrm{HNO}_{3}$ concentrations. The bands used were as follows:

$$
\begin{aligned}
& N_{p}(I V)-960 \text { millimicrons }(m \mu) \\
& N_{p}(V)-980 m \mu \\
& N_{p}(V I)-1230 m \mu
\end{aligned}
$$

The experimental data indicated the following:

1. A decrease in the concentration of the quadrivalent neptunium $\left(\mathrm{Np}^{+4}\right)$, pentavalent neptunium $\left(\mathrm{NpO}_{2}^{+}\right)$, and the hexavalent $\left(\mathrm{NpO}_{2}^{++}\right)$ions, as the concentrations of the $\mathrm{HNO}_{3}$ were increased. 
2. At $5.5 \underline{\mathrm{N} \mathrm{HNO}} \mathrm{H}_{3}$, most of the uncomplexed $\mathrm{Np}$ (IV) had disappeared.

3. Above $6 \underline{\mathrm{N}} \mathrm{HNO}_{3}$, only the spectrum of the $\mathrm{Np}(\mathrm{IV})$ complex was visible.

4. Over the 1 to $4 \underline{\mathrm{N}} \mathrm{HNO}_{3}$ range, the molar absorptivity of the $\mathrm{Np}(\mathrm{IV}), 1.23$ micron-band remained constant.

5. The formation of a nitrate complex with $N_{p}(V)$ was not observed in the $\mathrm{HNO}_{3}$ solutions above $3 \underline{\mathrm{N}}$.

6. Apparently the $\mathrm{N}_{\mathrm{p}}(\mathrm{V})$ was reduced by disproportionation to $\mathrm{Np}(\mathrm{IV})$, since only the spectrum of this specie was visible.

\section{EXPERIMENTAL}

Equipment: A Cary-14, ratio-recording spectrophotometer was used to record the 400 to $1400 \mathrm{~m} \mu$-spectral region. The instrument used a tungsten-lamp source with a 1P28 detector in the ultraviolet-visible region and a $\mathrm{PbS}$ detector in the near-infrared. Standard rectangular l-centimeter $(\mathrm{cm})$ silica cells were used for samples.

Conditions of the Experiment: Two different sets of conditions were used and will be fully described. In the first set, redox (oxidation-reduction) agents were employed to adjust the initial valence state of the neptunium for the spectrophotometric standards. The second set employed no redox agents, other than the $\mathrm{HNO}_{3}$ solution in which the valence states were measured.

Preparation of the Standards: A stock solution containing 4.8 grams per liter $(\mathrm{g} / \mathrm{l}) \mathrm{N}_{\mathrm{p}}$ was used to prepare the $N_{p}(\mathrm{IV})$, (V), and (VI) standard solutions. Three 10 -milliliter $(\mathrm{ml})$ portions of this solution were evaporated to incipient dryness and redissolved in appropriate oxidizing or reducing reagents to give $10-\mathrm{ml}$ master solutions of the neptunium-valence state desired.

$$
\begin{aligned}
& \mathrm{Np}(\mathrm{IV}) \text { - The stock-solution residue was redis- } \\
& \text { solved in } 5 \mathrm{ml} \text { of concentrated } \mathrm{HCl} \\
& \text { (hydrochloric acid) and } 0.1 \text { gram } \\
& \\
& \mathrm{NH}_{2} \mathrm{OH} \cdot \mathrm{HCl} \text { (hydroxylamine hydrochloride). }
\end{aligned}
$$

$$
\begin{aligned}
& \mathrm{Np}(\mathrm{V}) \text { - The stock-solution residue was } \\
& \text { redissolved in } 5 \mathrm{ml} \text { of } \mathrm{l} \mathrm{N} \mathrm{HNO}_{3} \\
& \text { and } \mathrm{l} \mathrm{ml} \text { of } \mathrm{H}_{2} \mathrm{O}_{2} \text { (hydrogen peroxide). }
\end{aligned}
$$

If a precipitate formed, the solution was heated until clear.

$$
\begin{aligned}
& \mathrm{Np}(\mathrm{VI}) \text { - The stock-solution residue was redis- } \\
& \text { solved in } 1 \mathrm{ml} \text { of concentrated } \mathrm{HNO}_{3} \text { and } \\
& \\
& 0.1 \mathrm{ml} \text { of } 0.5 \mathrm{M} \text { ceric nitrate. }
\end{aligned}
$$

The above master solutions were diluted to a final volume of $10 \mathrm{ml}$ with $1 \underline{\mathrm{N}} \mathrm{HNO}_{3}$. A spectral scan of each master solution showed that only the desired neptunium-valence state was present. From each master solution, a series of standards were prepared containing one $\mathrm{ml}$ of the master solution and $9 \mathrm{ml}$ of $1,2,3,4,5,6,7,8$, and $10 \underline{\mathrm{N}} \mathrm{HNO}_{3}$. Each standard, therefore, contained $0.48 \mathrm{~g} / \mathrm{l} \mathrm{Np}$. The concentration of the $\mathrm{HNO}_{3}$ was the variable.

Results Obtained on the Standards: The absorption spectra of the standards were recorded over the 400 to $1400 \mathrm{~m} \mu$ spectral range. $\mathrm{An}_{\mathrm{HNO}}$ solution of the same normality as that of the neptunium-containing sample solution was used in the reference beam. This negated any interference of the nitric acid spectrum in the neptunium spectrum. Spectral scans were made within 2 hours of the standard preparation.

Molar absorptivities were calculated using the absorbances found for the major absorption band of each of the species at each different nitric acid concentration. The bands used were as follows:

$$
\begin{aligned}
& N_{p}(I V)-960 m \mu^{5} \\
& N_{p}(V)-980 m \mu^{6} \\
& N_{p}(V I)-1230 m \mu^{7}
\end{aligned}
$$

Figure 1 shows the effect of increasing $\mathrm{HNO}_{3}$ concentration on the molar absorptivities of these bands. The curves thus indicated the decrease in the concentration of the uncomplexed $\mathrm{Np}^{+4}, \mathrm{NpO}_{2}^{+}$, and $\mathrm{NpO}_{2}^{++}$ as the $\mathrm{HNO}_{3}$ concentration was increased.

The curve for $\mathrm{Np}(\mathrm{IV})$ decreased rapidly, until at about $5.5 \underline{\mathrm{N}} \mathrm{HNO}_{3}$ concentration most of the uncomplexed $\mathrm{Np}$ (IV) had disappeared. Spectral scans of solutions containing higher concentrations of $\mathrm{HNO}_{3}$ showed only the spectrum of the hexanitrato complex. ${ }^{8}$ Examinations of the spectra of the $N_{p}$ (IV) solutions indicated that all the spectra were composed of a combination

\footnotetext{
${ }^{5}$ C. F. Metz and G. R. Waterbury, Loc. cit.

${ }^{6}$ lbid.

${ }^{7}$ C. A. Colvin. Loc. cit

${ }^{8}$ J. L. Ryan. Loc, cit.
} 


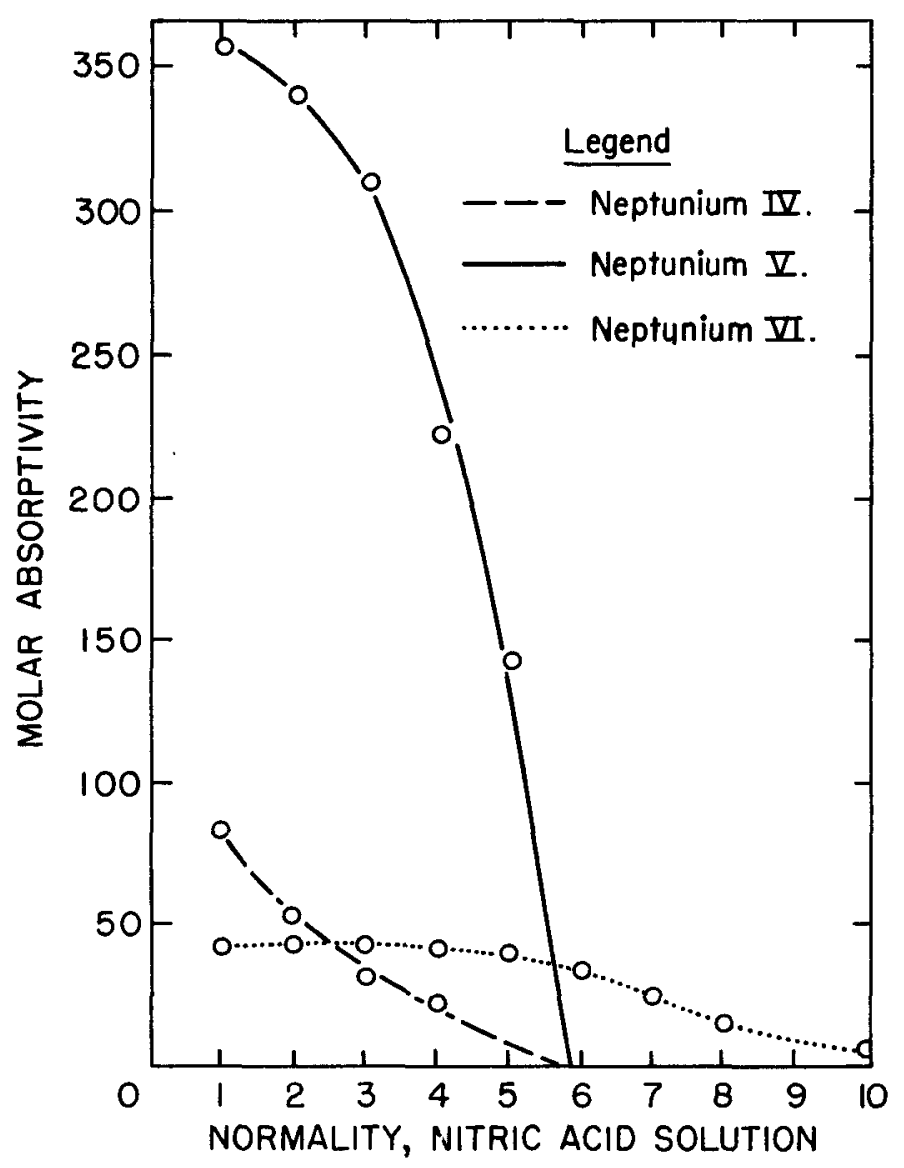

FIGURE 1. The Effect of Increasing Nitric Acid $\left(\mathrm{HNO}_{3}\right)$ Concentration on the Molar Absorptivities of Free Neptunium(IV), (V), and (VI) in Nitric Acid Solutions.

of only two basic spectra: the uncomplexed Np(IV) and the hexanitrato complex. No complexes containing fewer than six nitrate groups were detected.

The absorption of the $\mathrm{Np}_{\mathrm{p}}(\mathrm{V}), 980-\mathrm{m} \mu$ band also decreased rapidly with an increase in the $\mathrm{HNO}_{3}$ concentration of the solutions. In the $3 \underline{\mathrm{N}} \mathrm{HNO}_{3}$ solution, some of the $N_{p}(V)$ had been reduced to $N_{p}(I V)$ and the spectrum of the $\mathrm{N}_{\mathrm{p}}$ (IV) complex was visible. Above $6 \underline{\mathrm{N}} \mathrm{HNO}_{3}$, only the spectrum of the $\mathrm{Np}$ (IV) complex was visible.

Unlike the $\mathrm{N}_{\mathrm{p}}(\mathrm{IV})$ and $\mathrm{N}_{\mathrm{p}}(\mathrm{V})$ curves, the molar absorptivity of the $\mathrm{N}_{\mathrm{p}}(\mathrm{VI}), 1.23-\mu$ band remained constant over the 1 to $4 \mathrm{~N}_{\mathrm{HNO}_{3}}$ concentration range. Above this $\mathrm{HNO}_{3}$ concentration, there was a slow decrease in molar absorptivity with increasing nitric acid concentration.

Sample Preparation: The effect of the acid concentration on the $\mathrm{HNO}_{3}$ solution of $\mathrm{Np}$ containing no added reducing or oxidizing agent was next studied. A 10-mI aliquot of a stock solution containing $0.48 \mathrm{~g} / \mathrm{l} \mathrm{Np}$ was evaporated to dryness and redissolved in $1 \underline{\mathrm{N}} \mathrm{HNO}_{3}$. One-ml aliquots of this master solution were then diluted to $10 \mathrm{ml}$ with $1,2,3,4,5,6,7,8,10$, and $13 \mathrm{~N} \mathrm{HNO}_{3}$.

Results: The spectra of the sample solutions were recorded within the same time interval and in the same manner as for the standard solutions. The concentrations of $N_{p}(I V),(V)$, and (VI) in each sample solution were then calculated by the Beer-Lambert Equation using the molar absorptivities given in Figure 1. As can be noted in the figure, the molar absorptivities were dependent on the nitric acid concentration of the solution. Therefore, the calculations were made on the samples using the experimentally determined molar absorptivities found from the standards at corresponding nitric acid concentrations. Calculated percentages of $\mathrm{Np}(\mathrm{V})$ and $(\mathrm{VI})$ present in the sample solution at the various nitric acid concentrations are given in Table I. No Np(IV) was detectable in any of the sample solutions.

TABLE I. Amount of Neptunium(V) and Neptunium(VI) Present in Nitric Acid Solutions.

\begin{tabular}{ccc}
$\begin{array}{c}\text { Normality } \\
\text { of } \\
\text { Nitric Acid }\end{array}$ & $\begin{array}{c}\text { Percent } \\
\text { Neptunium(V) }\end{array}$ & $\begin{array}{c}\text { Percent } \\
\text { Neptunium(VI) }\end{array}$ \\
\cline { 3 - 3 } 1 & 6.8 & 93.2 \\
2 & 7.2 & 92.8 \\
3 & 7.2 & 92.8 \\
4 & 8.5 & 91.5 \\
5 & 12.5 & 87.5 \\
6 & 19.9 & 80.1 \\
7 & 21.3 & 78.7 \\
8 & 20.0 & 80.0 \\
10 & 3.7 & 96.3 \\
\hline
\end{tabular}

\section{DISCUSSION}

The acid concentration of solutions, in which $\mathrm{Np}$ is determined, presents a critical parameter in spectrophotometric methods. Previous studies of the effect of increasing $\mathrm{HNO}_{3}$ concentration in $\mathrm{Np}$ solutions had been concerned chiefly with establishing limits of $\mathrm{HNO}_{3}$ concentration for the absorption analytical methods. Further investigations were necessary to determine how the major absorption bands of $\mathrm{Vp}(\mathrm{IV})$, (V), and (VI) decrease in calculated molar absorptivity with an increase in $\mathrm{HNO}_{3}$ concentration. 
RFP-958
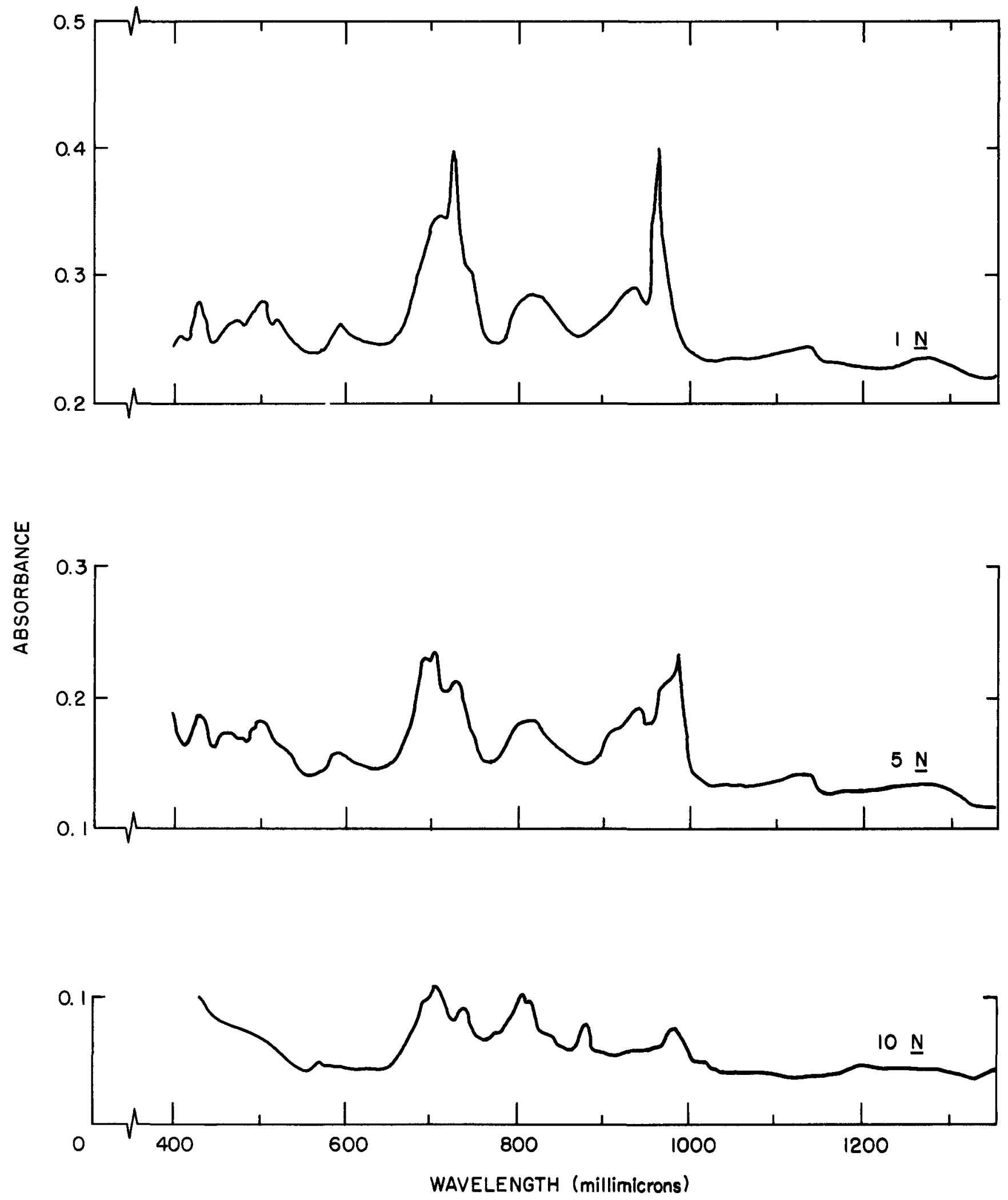

FIGURE 2. Absorption Spectra of Neptunium(IV) in 1, 5, and 10 Normal Nitric Acid.

4 
All of the actinides show strong tendencies to associate with coordinating groups to form complex ions in solution." The formation of the $\mathrm{Np}-\mathrm{NO}_{3}$ (neptuniumnitrate) complexes can be followed on the spectra presented in Figures 2, 3, and 4 of the $\mathrm{Np}_{\mathrm{p}}$ (IV), (V), and (VI) species in solutions of varying $\mathrm{HNO}_{3}$ concentration. The $\mathrm{Np}(\mathrm{IV})$-valence state would be expected to show the greatest degree of complex formation. ${ }^{10}$ This is indicated in the spectra of Figures 2 and 3. By comparing ${ }^{11}$ Figures 2 and 3 , it is apparent that the $\mathrm{Np}_{\mathrm{p}}(\mathrm{V})$ is reduced by disproportionation to $\mathrm{N}_{\mathrm{p}}(\mathrm{IV})$ as

${ }^{9}$ C. F. Metz and G. R. Waterbury, Loc. cit.

${ }^{10}$ Ibid.

${ }^{11}$ It should be noted in Figures $2,3,4$, and 5 , that it was desired to plot three different spectra corresponding to three different acidconcentration conditions on a single figure for comparison purposes. In order to give greater clarity and to prevent spectral superimposition, the ordinate, as denoted by three different zero values, was shifted by 0.1 absorbance unit for each of the three spectra. the $\mathrm{HNO}_{3}$ concentration is increased. The $\mathrm{N}_{\mathrm{p}}(\mathrm{IV})$ then follows the same complexing pattern as the original $\mathrm{N}_{\mathrm{p}}(\mathrm{IV})$ solution, and no evidence is visible of any spectrum that would be indicative of a $\mathrm{Np}(\mathrm{V})$-nitrate complex.

The spectrum of the $\mathrm{N}_{\mathrm{p}}(\mathrm{VI})$ standard, Figure 4, gives little indication of any absorption bands in the $10 \mathrm{~N}$ $\mathrm{HNO}_{3}$ solution. When the $\mathrm{Np}$ concentration was increased to $4.3 \mathrm{~g} / \mathrm{l}$ from $0.48 \mathrm{~g} / \mathrm{l}$, the absorption bands due to the $N_{p}(V I)$-nitrate complex could be seen. In Figure 5, the band at $1.13 \mu$ can be noticed increasing with $\mathrm{HNO}_{3}$ concentration. This band, the major absorption band of the $\mathrm{Np}(\mathrm{VI})$-nitrate complex, reaches a maximum absorbance in the $13 \mathrm{~N} \mathrm{HNO}_{3}$ solution. At this $\mathrm{HNO}_{3}$ concentration, less than 5 percent of the uncomplexed $N_{p}(V I)$ is calculated to be present.

FIGURE 3. Absorbance Spectra of Neptunium(V) in 1, 5, and 10 Normal Nitric Acid.

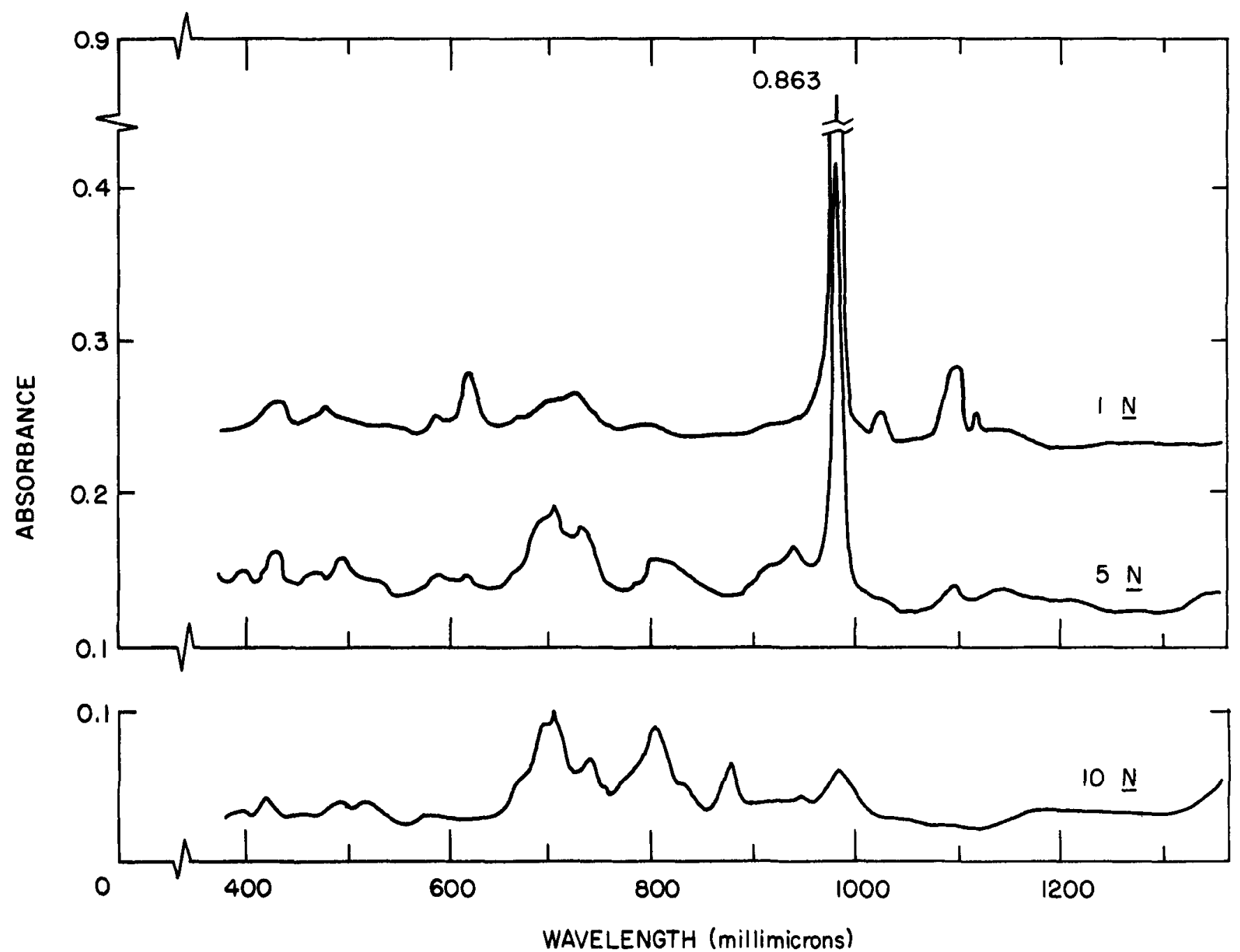


Spectral scans made on these solutions 24 hours later indicated a slow increase in $\mathrm{Np}_{\mathrm{p}}(\mathrm{V})$ in all solutions.

The formation of a nitrate complex with $\mathrm{Np}(\mathrm{V})$ had not been observed. In solutions containing $\mathrm{HNO}_{3}$ above $3 \underline{N}$ in concentration, the $\mathrm{Np}(\mathrm{V})$ disproportionated and only the $\mathrm{Np}_{\mathrm{P}}(\mathrm{IV})$-nitrate complex was visible. An attempt was made to prepare a nitrate complex of the pentavalent neptunium $\left(\mathrm{NpO}_{2}^{+}\right)$by addition of nitrate as calcium nitrate $\left[\mathrm{Ca}\left(\mathrm{NO}_{3}\right)_{2}\right]$ or aluminum nitrate $\left[\mathrm{Al}\left(\mathrm{NO}_{3}\right)_{3}\right]$. Solutions were made containing 0.52 grams per liter $(\mathrm{g} / \mathrm{l}) \mathrm{Np}$ in varying concentrations of the two salts and the spectra recorded. Results are shown in Table II. The effect of the same concentration of nitrate from $\mathrm{HNO}_{3}$ is given for comparison.

The decrease in absorbance of the $N_{p}(V)$ band in the $\mathrm{HNO}_{3}$ solution with increasing $\mathrm{HNO}_{3}$ concentration is
TABLE II. Effect of Added Nitrate on Pentavalent Neptunium Spectra.

\begin{tabular}{|c|c|c|c|}
\hline \multirow[b]{2}{*}{$\begin{array}{c}\text { Concentration } \\
\text { of } \\
\text { Nitric Oxide } \\
\end{array}$} & \multicolumn{3}{|c|}{$\begin{array}{c}\text { Absorbance of } 980-\text { Millimicrons, } \\
\text { Pentavalent Neptunium Band }\end{array}$} \\
\hline & $\begin{array}{l}\text { In } \\
\text { Nitric } \\
\text { Acid } \\
\end{array}$ & $\begin{array}{c}\text { In } \\
\text { Calcium } \\
\text { Nitrate }\end{array}$ & $\begin{array}{c}\text { In } \\
\text { Aluminum } \\
\text { Nitrate }\end{array}$ \\
\hline $1.2 \underline{\mathrm{N}}$ & 0.783 & 0.813 & 0.864 \\
\hline $3.6 \mathrm{~N}$ & 0.569 & 0.801 & 0.767 \\
\hline $6.0 \mathrm{~N}$ & 0.124 & 0.790 & 0.575 \\
\hline
\end{tabular}

caused by the $\mathrm{N}_{\mathrm{p}}(\mathrm{V})$ disproportionation. A decrease was recorded also in the other two salt solutions, but the spectra did not reveal any absorption bands other than those of the $N p(V)$ spectra. Evidence of a $N p(V)$ nitrate complex was therefore not observed in these solutions.

FIGURE 4. Absorption Spectra of Neptunium(VI) in 1, 5, and 10 Normal Nitric Acid.

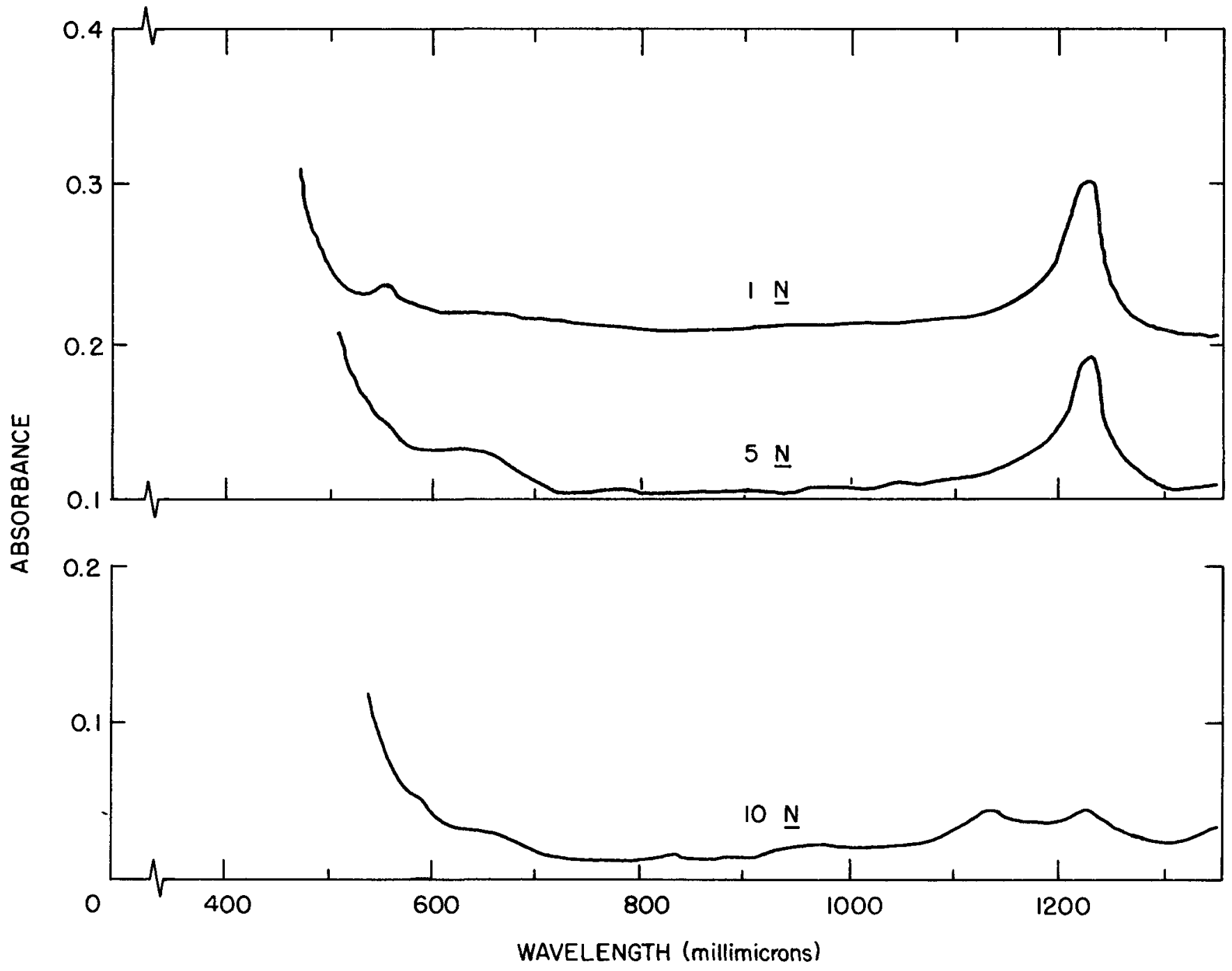


RFP-958
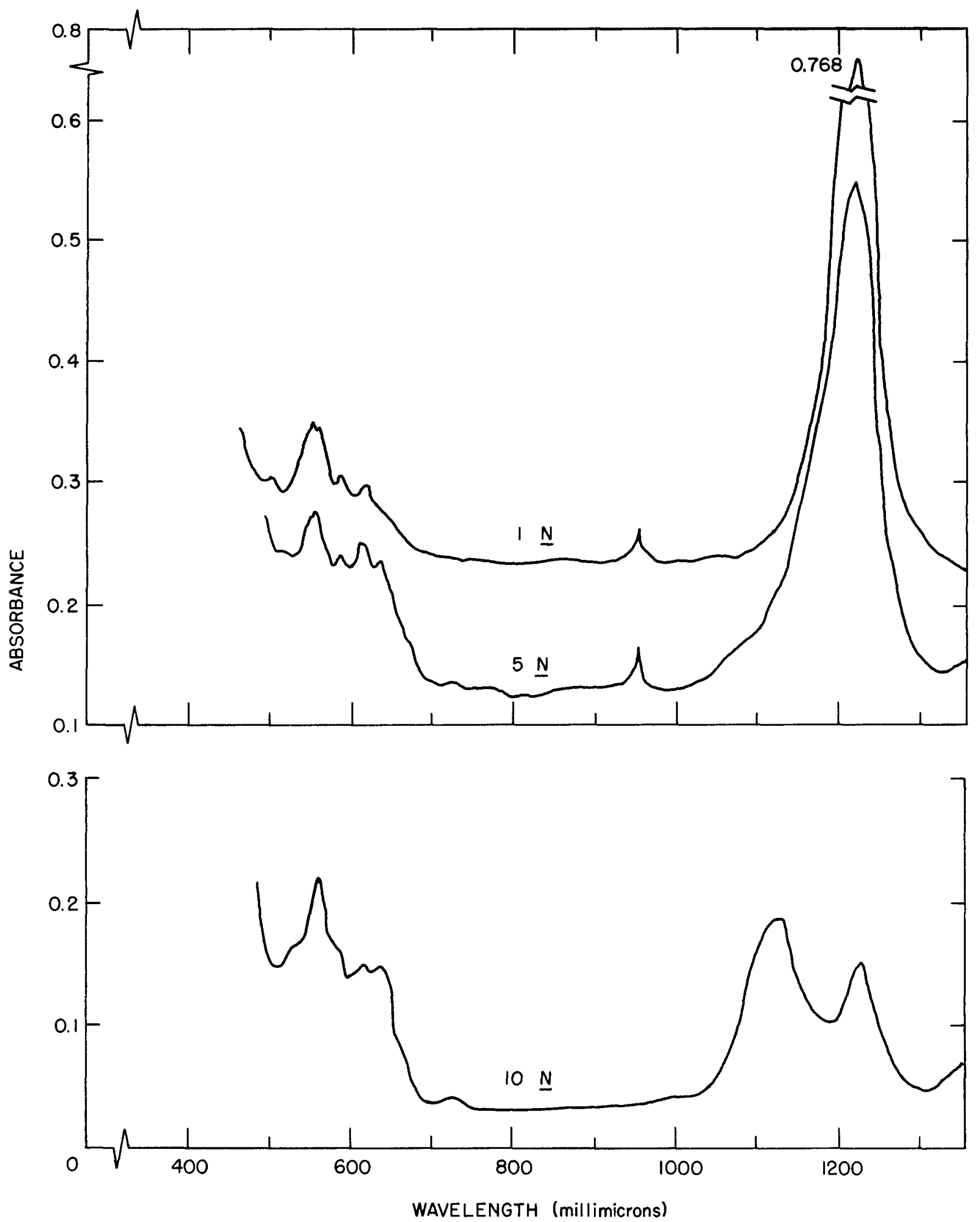

FIGURE 5. Absorption Spectra of Neptunium (sample) in 1, 5, and 10 Normal Nitric Acid. 